\title{
DEVELOPING ALTERNATIVE MATHEMATICS LEARNING MEDIA USE MATHEMATICA 8.0 OF INTEGRAL APPLICATION TO CALCULATE VOLUME OF SOLID OF REVOLUTION SUBJECT
}

\author{
Allim Setia Nugraha ${ }^{a}$, Sugiyarto \\ ${ }^{a}$ Mathematics Education Study Program, Universitas Ahmad Dahlan \\ Jln. Ringroad Selatan, Tamanan, Banguntapan, Bantul, Yogyakarta \\ allim.setia.nugraha@gmail.com, ${ }^{\mathrm{b}}$ sugiyartophd@gmail.com
}

\begin{abstract}
Learning mathematics in schools is still considered difficult and less enjoyable by the student. It needs to develop media that can support the learning of mathematics in schools. This study aims to plan, create and determine the feasibility study of the mathematics learning media of integral application to calculate the volume of solid of revolution subject. This research used the Research and Development ( $\mathrm{R}$ \& D) method. The step taken is a preliminary study, media development, validation by subject matter experts and media experts as well as due diligence by the user to obtain the final product in the form of media that is packaged with a CD. Collecting data used interview techniques, documents, and questionnaires. The instruments used in the data collection questionnaire tested by means of qualitative analysis. A data-processing technique used is quantitative descriptive. The results of this study in the form of media are packaged with a CD (Compact Disc). Stage of development of media produced is (1) a preliminary study; (2) development includes the study of the criteria of competence, media creation and validation by media experts and subject experts; (3) feasibility test of teaching media. To determine the feasibility of the media the test done in two stages. The result of phase I is $88.38 \%$ and phase II is $81.17 \%$. The data-processing of the trial is concluded that instructional media created with the category of very suitable.
\end{abstract}

Key Word: Media, Learning, Mathematics, Mathematica 8.0

\section{INTRODUCTION}

Education has an important role in human survival. One factor that determines the progress of a country is the success in carrying out education. Even in the laws of the Republic of Indonesia, it regulates the implementation of education and every citizen has the right to proper education. Education cannot be obtained instantly, but through the educational process according to the level of ability. To obtain education can be through non-formal education and formal education. Non-formal education was obtained since humans were born into a family and community environment. Along with the progress of nonformal education, humans as citizens get a structured and systematic formal education in schools and other educational institutions. Informal education, the basic knowledge taught and must have is reading, writing, and arithmetic. Therefore, language and mathematics have been taught starting from the level of kindergarten. In mathematics learning, to obtain mathematics it is necessary to go through a process according to the level taken.

Mathematics learning material and mathematics learning media as part of the input instrument component in the mathematics learning process have an important role in supporting the success of mathematics learning. The submission of mathematical material needs to use the right method because of mathematical objects that are abstract. The abstract mathematical object means that a mathematical object is a mental object that can be realized in the form of symbols and models. Students' difficulties in accepting direct mathematical objects make it difficult for students to master mathematical concepts correctly, are less able to grasp the meaning of mathematical symbols, and students are not fluent in using operations and procedures. Some of the students who were met revealed a saturation of mathematics because it was still difficult to understand the material and there was still little learning media used. Material that they think is difficult one of which is integral material that uses functions and graphs. These things led to the low interest of students in mathematics at school because mathematics is still considered a lesson that is difficult to understand and unpleasant. Various efforts have been made to increase the 
level of success of students in learning mathematics as well as to improve the quality of mathematics education, both by the government, schools, and teachers. However, the use of multimedia laboratory facilities in schools has not been utilized for the mathematics learning process. It was revealed by the mathematics study teacher who was met at the SMA Muhammadiyah Piyungan and SMA MBS Prambanan that the school had computer facilities but had not been used for mathematics learning because there were no computer applications available in schools that supported mathematics learning.

The use of learning media in learning mathematics greatly helps increase the effectiveness in the learning process and increases students' understanding of the understanding of complex and abstract material. Modeling abstract mathematical objects is a way to more quickly understand mathematical concepts correctly. Hamalik (Azhar Arsyad, 2011: 16) suggests that in addition to arousing students' motivation and interest, learning media can also help students improve understanding, present data interestingly and reliably, facilitate data interpretation and condense information. The use of media as a technology in the learning process in class often requires the effectiveness of the technology in improving students' abilities and understanding of the material presented. In the early stages, the media must show something that attracts students' attention. For this reason, the selection of learning media can influence the results given. The more advanced computer technology, the more mathematical material that can be visualized. But the advances in computer technology have not been fully utilized by teachers in presenting complicated material such as geometry, calculus and other material that requires visualization and animation to facilitate understanding. One of the materials that can be visualized is using a computer and not a lot of media is made, namely the application of integrals to find the volume of a rotating object. Making visualizations for mathematical material that tends to be complicated needs to be used software specifically designed for mathematics and its application.

One package of mathematical programs that have been developed a lot is Mathematica. Mathematica Software was developed by the company Wolfram Research, Inc. since 1988 and reached version 8.0 in 2010. The advantages of version 8.0 compared to the previous version are located in increasing 2D graphics into 3D and there are many other advantages. This software can be used as an alternative learning media that can be utilized by mathematics instructors. When introduced to this software, the mathematics teacher who was met stated interest in Mathematica software because it had not been utilized in mathematics learning at school. This program was chosen because Mathematica is a computer algebra system (CAS, Computer Algebra System) that integrates statistical computing capabilities (symbolic, numerical), visualization (graphics), programming languages and word processing into an easy-to-use environment. Mathematica is one of the means of choice in education, research, business and so on, especially for mathematical computing, both symbolic and numerical, the development of algorithms and applications, modeling and simulation, exploration, analysis, and data visualization.

\section{METHODS}

This research uses research and development methods or also called Research and Development $(\mathrm{R} \& \mathrm{D})$. This research is focused on developing alternative learning media in the form of application program packages and presentation tutorials using Mathematica. The R \& D method in this study used the steps shown in the figure below: 


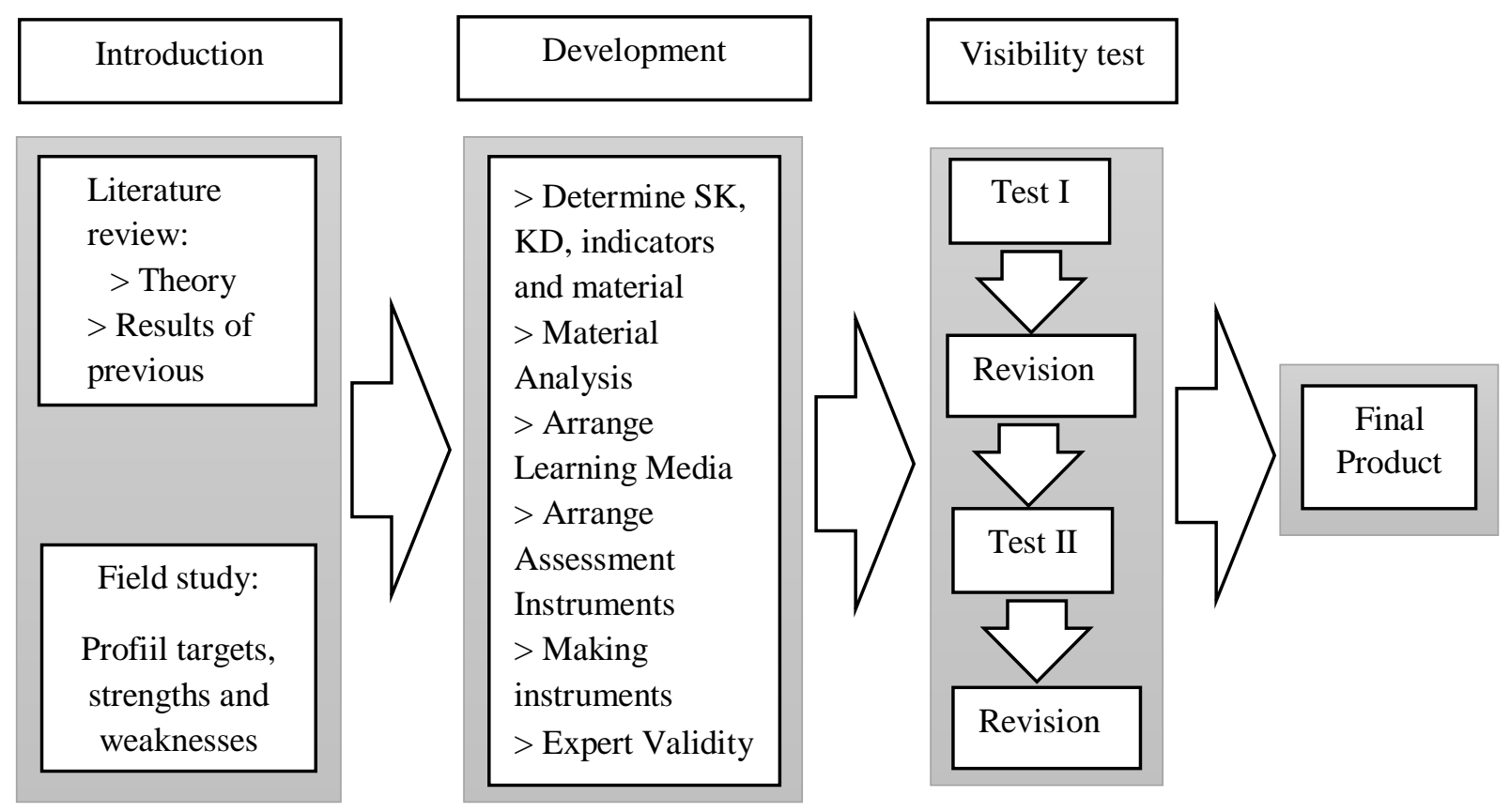

Picture 1. Steps of the R \& D Method

The preliminary study is the first step of research to explore the potential that can be developed and identify the problems found in the learning process. Potentials and problems can be obtained by searching directly to the place to be studied and can be based on research reports and documentation of activities of certain individuals or agencies. Supporting information can also be used to add innovation and strategy in the process of developing product designs. This additional information can be obtained by reviewing theories and various supporting data obtained from the place where the problem occurred.

Making product design is done after we get prospective user information, problems, development models from the preliminary study. This initial product design is still hypothetical which has not proven its feasibility. The feasibility of this design can be known through expert validation and testing for users. Validation by media experts and material experts was conducted to determine the extent to which the media developed could be used in the learning process. Assessment by experts refers to the research instrument. The results of the assessment are used as a reference to make improvements to the media developed. After improvements were made to the media developed, then a product feasibility test was carried out to find out that the learning media developed was feasible to use in the learning process at the MBB Prambanan High School, Sleman. The Feasibility test is conducted on prospective users twice in different classes using an assessment instrument in the form of a questionnaire. A test I was conducted in class XII of the male IPA then product revisions were made based on input from students. The second feasibility test was conducted at the male XII IPS class. After Test II is completed, the final revision is carried out then produces the final product.

Data collection techniques used are interviews, documentation, and questionnaires. Interviews were conducted for mathematics teachers and some students to obtain in-depth information about the problems to be studied. The documentation method in this study is to get a list of the names of students who will be the subject of research. Questionnaires are used to assess the suitability and feasibility of the media developed based on the material and purpose of its creation. The assessment instrument used was a questionnaire for the validator and students as users. The preparation of instruments refers to the grid of test instruments that have been made based on aspects of the quality of content, objectives, instructional and technical. Before the instrument is used, instrument validation needs to be done. The technique used is qualitative analysis. Included in the qualitative analysis is content validity and form. The analysis includes material aspects, construction, language and answers keys (Suparman, 2013: 29). 
The data analysis technique for the first stage which describes the development media learning program implemented in software and tests the level of validity and reliability of the program using quantitative descriptive analysis. The second stage which describes the feasibility of learning media implemented in the learning process of mathematics in the classroom on the subject of the integral application to calculate the volume of rotary objects also uses quantitative descriptive analysis. The numbers from the measurement calculation can be processed by adding up, compared to the expected number and obtained by the percentage (Suharsimi Arikunto, 1983: 140). The results of data analysis with quantitative descriptive techniques in the form of percentages to determine the feasibility status of learning media used in the learning process. After reaching the percentage, it was interpreted with qualitative sentences such as good (76\% - 100\%), quite good (56\% - 75\%), not good (40\% - 55\%), not good $(<40 \%)$ (Suharsimi Arikunto, 1983: 140). The scale of eligibility can be presented in the following table:

Table 1. Product Scaling Scale Table

\begin{tabular}{|c|c|c|}
\hline Percentage of Achievement & Value Scale & Interpretation \\
\hline $75 \%<$ percentage score $\leq 100 \%$ & 4 & Very Worthy \\
\hline $55 \%<$ percentage score $\leq 75 \%$ & 3 & Worthy \\
\hline $40 \% \leq$ percentage score of $\leq 55 \%$ & 2 & Less Worthy \\
\hline$<40 \%$ & 1 & Not Worthy \\
\hline
\end{tabular}

\section{RESULTS AND DISCUSSION}

This research has succeeded in developing the mathematics learning media using Mathematica 8.0 software for class XII students on the subject of an integrated application to calculate the volume of rotary objects. This mathematics learning media is packaged in a CD (Compact Disc). This learning media consists of several parts, namely: (1) Navigation Menu, (2) Intro, (3) Instructions for Use, (4) Table of Contents, (5) Material and (6) Training. Each submission of material content is accompanied by an animated graph that can be moved by the user.

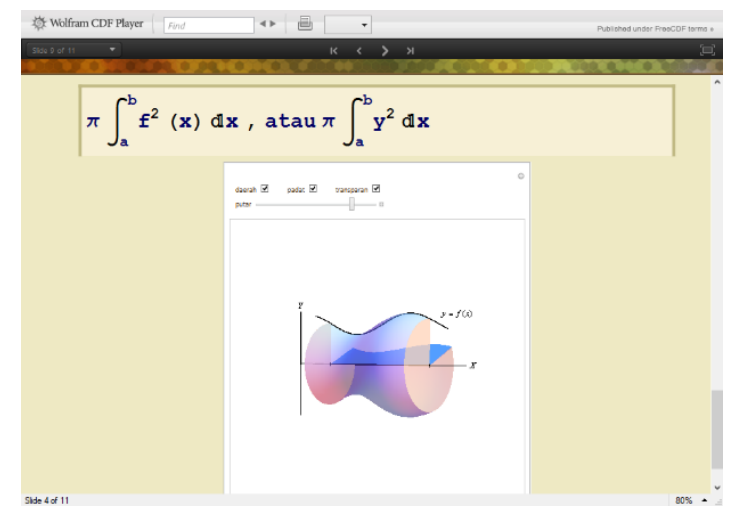

1. Development

Picture 2. One example of the contents of the material

The media development phase follows the steps as follows:

a. Phase I

1) Analyzing the competency of the integral application discussion to calculate the volume of rotary objects.

2) Collect references (reference books) regarding the subject matter of the integral application to calculate the volume of rotary objects. 
3) Plan and choose the type of learning media that will be used. The learning media chosen are learning media that are packaged in learning Compact Disc (CD) pieces that can be used with computer devices.

b. Phase II

1) Making learning media using the Mathematica 8.0 program. The sequence of making learning media is a) The initial design includes flow design and storyboard making. b) Display design. The stage of display design is an illustration of the design of the learning program that is arranged in sequence according to the initial design. c) Making media that is the process of translating designs into actual appearance. d) Testing learning media by running the finished media and then packing it in CD.

2) Consult the media to the supervisor.

3) Creating a testing instrument to assess the feasibility of the media then instrument validation.

c. Stage III

Validating and evaluating the feasibility of learning media from material experts and media experts. The percentage obtained from media experts is $91.7 \%$ and material experts are $76.3 \%$. After revising the product, the user is tested.

2. Feasibility Test

Learning media assessment was carried out by 17 students in the first test and 16 students in the second test. The results of the calculation of the feasibility of learning media are presented in the following table.

Table 2. Results of the calculation of the feasibility of learning media

\begin{tabular}{|l|c|c|c|c|c|}
\hline No & Evaluator & $\begin{array}{c}\text { Observation } \\
\text { Score }\end{array}$ & $\begin{array}{c}\text { Expected } \\
\text { Score }\end{array}$ & $\begin{array}{c}\text { Advisability } \\
(\boldsymbol{\%})\end{array}$ & Category \\
\hline 1 & Test I & 70,71 & 80 & 88,38 & Very worthy \\
\hline 2 & Test II & 64,94 & 80 & 81,17 & Very worthy \\
\hline \multicolumn{2}{|c|}{ Total } & 135,65 & 160 & 84,78 & Very worthy \\
\hline
\end{tabular}

From the percentage of the feasibility of learning media, it can be seen that the learning media is included in the very feasible category.

\section{CONCLUSION}

Based on the results of the research and discussion, conclusions are obtained as follows:

1. To plan and make or produce learning media can be done in several steps, namely: (1) Preliminary study, (2) development which includes analysis of competency standards, collecting references, planning, making media, validating media experts and material experts, and (3) feasibility test to determine the feasibility of learning media made.

2. The results of the feasibility test of mathematics learning media in the first test amounted to $88.38 \%$ and in the second test $81.87 \%$. From the feasibility test twice, it was concluded that the learning media made included in the category was very feasible.

\section{REFERENCES}

Arikunto,Suharsimi.1983.Prosedur Penelitian: Suatu Pendekatan Praktek.Jakarta: Bina Aksara.

Arsyad, Azhar.2011.Media Pembelajaran. Jakarta:Rajawali Pers.

Hudjono,Herman.1979.Pengembangan Kurikulum Matematika dan Pelaksanaannya di Depan Kelas. Surabaya:Usaha Nasional.

Razali,Muhammad.2008.Cara Mudah Menyelesaikan Matematika dengan Mathematica.Yogyakarta:Penerbit Andi.

Suparman.2013.Metodologi Penelitian Pendidikan.Yogyakarta:MIPA UAD Press. 